\title{
Farmers' Responses to the Adoption of Organic Rice Farming in Buleleng Regency, Bali
}

\author{
I Putu Sriartha ${ }^{1}$, I Putu Gede Diatmika ${ }^{1}$, Putu Yunartha Pradnyana Putra ${ }^{1}$ \\ putu.sriartha@undiksha.ac.id, gede.diatmika@undiksha.ac.id, \\ putuyunartha.pradnyana.putra@undiksha.ac.id \\ ${ }^{1}$ Universitas Pendidikan Ganesha, Indonesia
}

\begin{abstract}
This study aimed to determine the response of farmers and perceived barriers in adopting organic rice farming. The study was conducted in three subaks in the Banyumala River Basin, Buleleng Regency.The three subaks were selected purposively based on considerations of upstream, middle and downstream agroecosystems. Data were collected from key informants consisting of field agricultural extension workers, subak head and selected farmers, using field observations and in-depth interviews. Data analysis was carried out using qualitative descriptive techniques through the stages of reduction, presentation, interpretation and conclusions. The response of farmers to the adoption of organic farming is negative. Cognitive response is better than attitude response, while the worst response is behavioral response.The response of farmers in the upstream agroecosystem is better than the response of the farmers in the middle and downstream agroecosystems. The obstacles that cause farmers to be unresponsive to the adoption of organic rice farming stem from government policies and programs that are not yet optimal, a market environment that does not benefit farmers, farmers' internal constraints and the ineffective role of subak.
\end{abstract}

Keywords: Farmer's response; organic rice farming.

\section{Introduction}

The development of organic agriculture is a response to the failure of the Green Revolution in maintaining land fertility, biodiversity, water, and the health of food products. In Indonesia, the Green Revolution began in 1960 with a farming intensification program that has succeeded in delivering Indonesia to be self-sufficient in rice in 1984. Rice productivity increased sharply from 2.5 tons/ha in 1968 to 4.4 tons/ha in 1984 [1]. But behind this success, the Green Revolution has had a negative impact in terms of depletion of natural resources, environmental degradation, especially land and water, human health problems and the increasing threat of extreme climate change [1]-[3]. The Green Revolution as an agricultural system based on high chemical inputs is considered contrary to a sustainable agricultural system.

The International Federation of Organic Agriculture Movement or IFOAM [4] and Raut, et.al.[5], state that organic farming systems are holistic production systems to improve and develop the health of agroecosystems, including biodiversity, biological cycles, and biological activities land. Organic agriculture emphasizes the application of management practices that prioritize the use of inputs from waste from cultivation activities that are in situ by considering 
the adaptability to local conditions. The main characteristic of organic farming is to use local resources in situ and reduce the adoption of external inputs that are chemically synthetic. The goal of organic agriculture is focused on creating a balance between production, social and ecology in the long term, so that organic agriculture is basically a form of sustainable agriculture. Organic farming is rated by [6] as the most feasible farming system to reduce negative impacts on the environment, provide better food products to consumers and increase farmers' income.

The Indonesian government began to develop organic agriculture through the 'Go Organic' policy in 2010. Since then, organic farming has begun to develop, both in area and in the products produced. However, this development has not been as fast as expected.The adoption of organic farming at the individual farmer level and at the farmer group level is relatively small. This situation is caused by a number of obstacles, including market constraints, lack of understanding of organic farming, not yet optimal role of farmer organizations or groups, the certification process which is considered difficult by farmers. Interest and response to organic farming has started to grow, but has not been evenly distributed in various agro-ecosystems [3]. Response is defined as a reaction or response to a particular object or situation due to a stimulus received by the five senses. These stimuli can come from outside and or from within the individual. The form of the response can be positive, negative, can be pleasant or unpleasant, interested or not interested, willing or unwilling to accept or apply. Response can be synonymous with attitude [7]. Farmers' responses to technological innovations can be in the form of responses related to knowledge, responses related to attitudes, and responses related to real behavior [8]. In this study, the response of farmers is interpreted as a response or reaction of rice farmers to organic farming that has been introduced previously. The responses studied include knowledge responses (cognitive), attitude responses (persuasion), and behavioral responses.

Rice farmers in Bali are tied to the subak organization. Subak's role as a traditional farmer organization is very strategic as a vehicle for distributing technological innovations and agricultural information to the farmer level, as a forum for empowering farmers and accelerating the implementation of development programs from the government [9]. Subak is a traditional Balinese farmer group that is thousands of years old and still exists today. The role of subak in realizing sustainable agricultural development has been recognized by the world and therefore Unesco in 2012 designated subak as a world cultural heritage that must be preserved. Subak, which is based on the Tri Hita Karana philosophy, has proven its sophistication in implementing the practice of natural farming systems with local inputs. This study aims to analyze the response of lowland rice farmers to organic farming and the constraints faced. 


\section{Method}

This study used a descriptive research design. The location of the research was carried out in three subaks of rice fields in the Banyumala Watershed (DAS) Buleleng Regency. The three subaks were chosen purposively by considering the agroecosystem. Based on these considerations, it is determined that Subak Kedu represents the upstream agroecosystem, Subak Babakan Dauh Sema represents the middle agroecosystem, and Subak Uma Panji represents the downstream agroecosystem. The data collected includes data related to farmer responses (cognitive, affective and behavioral responses) and constraints in the adoption of organic agriculture, data related to the role of subak in driving organic agriculture. The key informants who become the source of the data were 1 agricultural extension workers, 3 subak and 3 farmers in each subak. The research data were collected by interview and field observation techniques. Data analysis was carried out using descriptive techniques through the stages of data reduction, presentation and interpretation and drawing conclusions.

\section{Result and Discussion}

\subsection{Farmers' Responses to the Adoption of Organic Rice Farming}

There are three dimensions of the response of the farmers were investigated. First, cognitive response relates to mastery of knowledge and understanding of farmers about organic farming which includes understanding of organic farming, benefits, principles or basic characteristics of organic farming and steps of organic rice farming techniques. Second, the attitude response of farmers was examined from their interest in organic farming, their agreement with the development of organic agriculture and their willingness or ability to implement it. Third, behavioral responses are related to real actions in the adoption of organic rice farming. The results showed that the cognitive responses of farmers to the adoption of organic rice farming were relatively the same in the three agroecosystems. Attitude responses and behavioral responses of farmers showed variations, where the attitudes of farmers in the upstream agro-ecosystem gave a more positive response to organic rice farming than the other two agro-ecosystems. The summary of research results on farmer responses to the adoption of organic rice farming is presented in Table 1.

The responses of farmers in the middle and downstream agro-ecosystems are in a low (negative) to very low (very negative) position, while the responses of farmers in upstream agro-ecosystems tend to be positive. This positive response began with the emergence of the idea of Subak Head in 2016 which pioneered the development of organic rice in Subak Kedu and government support through the Buleleng Regency Agriculture Office. The following is a summary of the results of interviews with Head of Subak Kedu (Made Sridana) and Field Extension Officer (Ketut Sutama).

" Organic farming in this subak started with an invitation from a previous subak head who was also a staff employee at the Buleleng Regency Agriculture Office. The invitation was followed up in a subak meeting which agreed to grow organic rice. Then get support from the Department of Agriculture in the form of guidance, organic fertilizer assistance, certification fees, and organic fertilizer processing tools“" (Interview with Subak head on August 7, 2021). 
"The development of organic rice farming in Subak Kedu was due to the idea of subak head at that time (in 2016) who also happened to be an employee of the Agriculture Service. Due to its location upstream where the water is still clean free from chemical pollution and household waste, the government supports the development of organic rice farming in the area" (Interview with PPL staff on August 8, 2021).

Table 1. Farmers' Response to Organic Rice Farming Adoption

\begin{tabular}{lccc}
\hline \multicolumn{1}{c}{ Dimensions and Indicators } & \multicolumn{3}{c}{ Agroecosystem } \\
\cline { 2 - 4 } Cognitive Responses & Downstream & Midlle & Upstream \\
\hline 1. Definition of organic (paddy) farming & -1 & -1 & +1 \\
2. Benefits & +1 & +1 & +2 \\
3. Basic principles/characteristics & -1 & -1 & +1 \\
Attitude Responses & & & \\
1. Interest & -1 & +1 & -1 \\
2. Development agreement & -1 & -1 & -1 \\
3. Willingness/ability to apply & -2 & -2 & \\
Behavioural Responses & & & +2 \\
1. Organic farming experience & -2 & -2 & -1 \\
2. Application consistency & -2 & -2 & +1 \\
3. Variety of organic technology used & -2 & -2 & \\
\hline
\end{tabular}

$+2=$ very positive; $+1=$ Positive $;-2=$ Not positive; $-1=$ Less positive

The key informant's statement above means that the process of adopting organic agriculture, including other agricultural technology innovations, begins with the emergence of actors who are pioneers of innovation. These actors can come from the farming community and from outside the community (government, NGOs, PPLs, researchers, and other actors who are media sources of information channels). This is in line with the opinion [10] that information communication channels in the form of various sources of information, information media and credibility of information sources are the beginning of an adoption of agricultural innovations. The results of the study [11] revealed that the success of Subak Wangaya Wetan Tabanan Bali in developing organic rice farming was initiated by the emergence of pioneer actors in the farming community which were then supported by external actors, especially from the Agricultural Technology Research Institute.

\subsection{Why Farmers Reject to Organic Rice Farming?}

The results of the study in Table 1 show that in general farmers are not responsive to organic rice farming. The worst farmer response was behavioral response, followed by attitude response and the best was cognitive response. This indicates that between knowledge, attidutes of farmers toward organic farming adoption is not always linear. According to [12] the stages of an adoption starting from first knowing and being aware of a new idea or practice, being interested (looking for information stubs), evaluating (assessing its benefits), trying and finally adopting, is not a definite sequence. It can happen before the adoption stage the response is positive and at the adoption stage farmers respond negatively if they feel they do not get the benefits so that such farmers do not continue the adoption. The symptoms of the unresponsiveness of farmers to organic rice farming and the withdrawal symptoms of 
farmers in Subak Kedu in adopting organic farming are recorded from the following interviews.

"Farmers in Subak Kedu are unable to continue organic rice farming because of many obstacles and this has become an agreement in the subak member meeting. Subak is unable to pay the cost of organic certification which expires this year, amounting to Rp.28 million/3 years plus survey costs of 4.7 million/year. Production is declining and marketing is difficult, while farmers in this subak are $50 \%$ smallholders. The immediate change of chemical fertilizers to organic fertilizers suggested by the government turned out to be not good" (Interview with Head of Subak Kedu August 14, 2021).

"I very rarely use organic fertilizers, the assistance from the government is uncertain and small, the results of organic fertilizers can only be seen in a long time and are not as high as chemical fertilizers. If chemical fertilizers have a quick effect, once they are fertilized within a week, the rice plants will already thrive. That's why until now I use chemical fertilizers even though the need for a hectare continues to increase due to soil that is already immune. In addition, organic rice processing is very complicated, requires a lot of labor and time and the risk of failure is also high, while most of the farmers here are smallholders and smallholders with an area of under 40 acres. (Interview with farmer Uma Panji August 15, 2021).

Based on the results of these interviews, identified three sources of obstacles or obstacles in the development of organic rice farming, namely: constraints originating from the government, constraints from the market environment, constraints from individuals and groups of farmers (Figure 1).

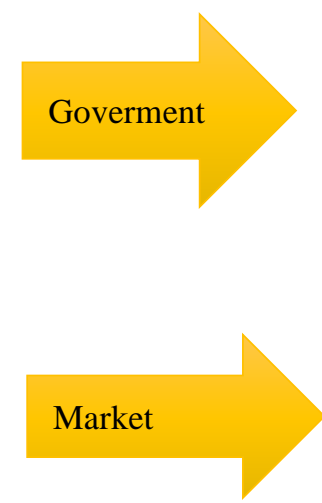

- Revolutionary introduction process and approach

- The organic certification process is complex and expensive

- Lack of organic infrastructure and facilities

- Training / counseling through schools has not been intensive

- The Green Revolution Program traps farmers

- Lack of empowerment of local farmer groups (subak)

- Difficult access to organic product markets

- Premium prices for organic products are low

$\begin{array}{ll}\bullet & \text { Decreased production and profits } \\ \bullet & \begin{array}{l}\text { Don't want to take risks because the majority are } \\ \text { smallholders } \\ \text { Farmer and } \\ \text { group/subak }\end{array} \\ \bullet & \text { Average ownership of small paddy fields } \\ \bullet & \text { Organic rice management is difficult and expensive } \\ \bullet & \text { Subak's role is not optimal } \\ \bullet & \text { Difficult to get organic input } \\ - & \text { Farmers are not full time on the farm } \\ & \text { Lack of skills and experience in organic farming }\end{array}$

Figure 1. Constraints to Adoption of Organic Rice Farming 
The results of this study are strengthened by the results of research [13], that the obstacles that farmers complain about are complex and expensive organic certification rules, lack of assistance for agricultural infrastructure and facilities, difficulty in accessing markets, access to agricultural inputs and the weak role of the organization. Furthermore [2] revealed that the main obstacles to the adoption of organic rice farming are the lack of assistance, training and services from the government, the certification process is complicated, it is difficult to sell organic products, the price is not feasible, while the constraints at the farm level are difficulties in obtaining organic inputs, volume and declining production quality, and labor shortages. The role of farmer organizations, in this case subak in driving organic rice farming, has not shown the expected performance due to internal constraints of subak and external pressure. Subak's role is only limited to being a distributor of programs that come from outside parties, especially the government. The role of subak as an empowerer, as a forum for learning knowledge and training in organic farming skills is still low. Lansing, et.al [14] revealed that subak is basically a local organization in the field of rice field irrigation that is adaptive, but with external pressures such as the introduction of chemical technology in the form of the Green Revolution causes subak to be affected and dependent on the use of chemical fertilizers and pesticides. on a large scale and have an impact on the emergence of uncontrolled pest and plant diseases. The existence of subak that is getting weaker is expressed by [15] that currently the existence of subak in Bali is facing severe external pressures and threats and some subaks have experienced discontinuity or extinction. Debilitating external threats include population development, urban area development, tourism which causes subak rice fields to narrow, the exodus of farmers to non-agricultural work, and the weakening of farmers' commitment to their farming land.

\section{Conclusion}

The response of farmers to organic rice farming is negative. Judging from the response dimension, it shows that the farmer's cognitive response is better than the attitude response and the worst response is the behavioral response. Judging from the agroecosystem, farmers in the upstream agroecosystem have the best response compared to the middle and downstream agroecosystems. Government policy factors, the role of local pioneer farmers and the quality of irrigation water encourage farmers' positive response to organic rice. The occurrence of rejection of adoption and failure of the sustainability of organic rice farming is caused by the obstacles felt by farmers. These constraints stem from government policies and programs that have not been optimally felt by farmers, a market environment that is not favorable to farmers, and social, economic and cultural factors of farmers, both individually and in farmer groups, such as the ineffective role of subak.

\section{Acknowledgements}

Appreciation and thanks are conveyed to LPPM Universitas Pendidikan Ganesha, which has assisted in funding research through basic research contracts for the 2021 fiscal year, number: 399/UN48.16/LT/2021 dated April 16, 2021. Many thanks are conveyed to the Field Agricultural Extension Officer, Subak head and farmers of Subak Kedu, Subak Babakan Dauh Sema, and Subak Uma Panji in the Banyumala Buleleng River Basin who have volunteered to serve as informants in this research. 


\section{References}

[1] Jahroh,Siti, "Organic Farming Development in Indonesia: Lessons Learned from Organic Farming in West Java And North Sumatra.," Innov. Sustain. Dev. Agricuktural Food (ISDA 2010), pp. 01-11, 2010.

[2] Mohamed Haris, Nur Hahiah, "Factors Influencing Decision to Farm Organic Practices in Malaysia," New Castle University, 2019.

[3] Mayrowani, Henny, "Pengembangan Pertanian Organik Di Indonesia," FORUM Penelit. AGRO Ekon., vol. 30, no. 2, pp. 91-108, 2012.

[4] IFOAM One Earth, Many Hands, "Annual Repport. International Federation of Organic Movement.," 2008.

[5] Raut,V.D., D.D. Raut and S.K. Deshpande, "A Boost of Organic Farming To Farmers," Guj. J. Ext. Edu, vol. 29, no. 2, pp. 159-162, 2019.

[6] Ziga Malek, Toen F. Tieskens, Peter H Verburg, "Explaining the Global Spatial Distribution of Crop Organic Producers.," Agric. Syst., pp. 01-10, 2019.

[7] Anggi Sahru Romdon, Komalawati dan Johanes Amirrullah, "Persepsi dan Respon Petani Terhadap Komponen Teknologi Jajar Legowo Super Di Kabupaten Tegal," JASEP, vol. 6, no. 1, pp. 35-46, 2020.

[8] Apprilliza Naura,Lies Sulistyowati, Maman Haeruman Karmana, "Respon Petani Padi sawah terhadap Kebijakan Insentif dan Disinsentif Di Kota Tasikmelaya Jawa Barat.," Mimb. Agribisnis, J. Pemikir. Masy. Ilm. Berwawasan Agribisnis, vol. 6, no. 1, pp. 155-177, 2020.

[9] Adawiyah,Cut R., Sumarjo, Eko S. Mulyani, "Faktor-Faktor Yang Mempengaruhi Peran Komunikasi Kelompok Tani Dalam Adopsi Inovasi Teknologi Upaya Khusus (Padi, Jagung, Kedelai) Di Jawa Timur,” J. Agro Ekon., vol. 35, no. 2, pp. 151-170, 2017.

[10] Rushendi, Sarwititi sarwospradjo, Retno Sri Hartiti Mulyadari, "Pengaruh Saluran Komunikasi Interpersonal Terhadap keputusan Adopsi Inovasi pertanian Bioindustri Integrasi Serai Wangi-Ternak Di Provinsi Jawa Barat,” J. Agro Ekon., vol. 34, no. 2, pp. 135-144, 2016.

[11] Euis Dewi Yuliana, Ajeg Subak Dalam Transformasi Pertanian Modern Menuju Pertanian Organik. Denpasar: UNH Press, 2020.

[12] Ray, G.L, Extension Communications and Management (Third Edition). Calcuta: Naya Prokasih 2016 Bhidan Sarani, 1998.

[13] Tri Bastuti Purwantini dan Sunarsih, "Pertanian Organik: Konsep, Kinerja, Prospek, dan Kendala.," Forum Penelit. Agro Ekon., vol. 37, no. 2, pp. 127-142, 2019. 